\title{
TERAJU
}

Teraju: Jurnal Syariah dan Hukum

Volume 02 Nomor 02, September 2020

DOI: https://doi.org/10.35961/teraju.v2i02.162

\section{Zakat Sebagai Pengentasan Kemiskinan dan Pembangunan Perekonomian Umat (Telaah Pengelolaan Zakat Pada Masa Khulafaur Rasyidin)}

\author{
Mutia Azizah Nuriana \\ mutia.arizab08@gmail.com

\section{Khomarudin Achmad \\ IAIN Surakarta \\ banxmod@gmail.com}

Sekolah Tinggi Agama Islam Mulia Astuti Wonogiri

\begin{abstract}
Abstrak
Artikel ini membahas secara deskriptif mengenai fungsi zakat dalam kehidupan masyarakat dimasa khulafaurasyidin. dengan menggunakan pendekatan sejarah social menjadikan kehidupan sosial-ekonomi pada masa Khulafaur Rasyidin, khususnya berkaitan dengan penerapan zakat. Pada masa pemerintahan Khulafaurasyidin zakat menjadi instrument utama dalam mengentaskan kemiskinan maupun membangun perekonomian umat. Kebijakan yang dikeluarkan para khalifah semua mengarah kepada pengentasan kemiskinan dan juga pengembangan perekonomian umat. Dalam mengentaskan kemiskinan melalui sarana pelayanan dan bantuan. Sedangkan dalam pembangunan perekonomian umat melalui pendayaguanaan zakat, Zakat memiliki peran dan fungsi secara bersamaan, secara sepiritual dan social maka zakat dapat menjadi solusi di dalam masalah kemiskinan dan pembangunan perekonomian.
\end{abstract}

Kata kunci: Zakat, Khulafaurasyidin, pengentasan kemiskinan, pembanguan perkonomian umat

\section{Abstract}

This article discusses the function of zakat in people's lives during the khulafaurasyidin period descriptively. By using a social history approach, the socio-economic life during the Khulafaur Rasyidin period, particularly in relation to the application of zakat. During the reign of 
Khulafaurasyidin zakat became the main instrument in alleviating poverty and building the economy of the people. The policies issued by the caliphs all led to poverty alleviation and also the economic development of the people. In alleviating poverty through service and assistance facilities. Meanwhile, in the economic development of the people through zakat empowerment, Zakat has a role and function simultaneously, spiritually and socially, so that zakat can be a solution to problems of poverty and economic development.

Keywords: Zakat, Khulafaur Rasyidin, poverty alleviation, community economic development

\section{Pendahuluan}

Berdasar data BPS keberadaan Ekonomi Indonesia pada triwulan pertama pada tahun 2020 bertambah $2,97 \%$ dibanding pada posisi di triwulan pertama tahun 2019. Perolehan Pertumbuhan ekonomi didorong dari semua sector peluang usaha, dengan perolehan pertumbuhan ekonomi tertinggi dicapai oleh Jasa Keuangan dan Asuransi sebesar 10,67 \%; diikuti oleh Jasa Kesehatan dan Kegiatan Sosial sebesar $10,39 \%$; sedangkan Informasi dan Komunikasi sebesar 9,81\%. Berdasarkan sumber pertumbuhan ekonomi Indonesia pada triwulan pertama tahun 2020 dari data BPS, sumber pertumbuhan tertinggi berasal dari Sektor Usaha, sector Informasi dan Komunikasi sebesar 0,53 $\%$; diikuti Jasa Keuangan dan Asuransi serta Industri, dengan Pengolahan masingmasing sebesar $0,44 \%$; sedangkan Konstruksi sebesar 0,29 \%. Sementara pertumbuhan ekonomi Indonesia dari sektor usaha lainnya sebesar $1,27 \%{ }^{1}$

Pada data BPS Angka kemiskinan secara nasional Pada bulan Maret tahun 2019, tercatat bahwa Indonesia berada pada digaris kemiskinan Rp425 250,/kap/bulan.dengan jumlah penduduk miskin di Indonesia yang mencapai 25,14 juta orang atau 9,41\%. perubahan tingkat kemiskinan selama periode tahun 1999

1 Pertumbuhan Ekonomi Indonesia Triwulan I-2020 No. 39/05/Th. XXIII, 5 Mei 2020 s/d tahun 2019 mengalami penurunan yang baik. Pada tahun 1999 berdasar data BPS jumlah penduduk miskin tercatat sebesar 47,97 juta orang (23,43\%), pada Maret 2019 menurun menjadi 25,14 juta orang $(9,41 \%)$. Periode yang sama pada tahun 1999 tercatat, indeks kedalaman kemiskinan dan indeks keparahan kemiskinan menunjukan penurunan secara berturut-turut sebesar 4,33 dan 1,23, pada Maret 2019 mnunjukkan penurunan menjadi 1,55 dan $0,37 .^{2}$

Khulafaur Rasyidin merupakan pemimpin umat setelah Rasulullah saw wafat sebagai Kepala Negara pemegang kebijakan dikenal sangat arif dan bijaksana. ${ }^{3}$ Sebagai pengganti Rasulullah saw yang memegang hak untuk bertindak dan mengatur berbagai kegiatan kenegaran. Khulafaur Rasyidin juga merupakan wali Allah yang mengemban amanah dalam dakwah serta melindungi rakyatnya dari ancaman penindasan. Khulafaur Rasyidin yang dikenal adalah Abu Bakar, Umar bin Khattab, Utsman bin Affan dan Ali bin Abi Thalib. ${ }^{4}$ Dari masing masing empat khalifah tersebut memiliki kebjakan masing-masing untuk

\footnotetext{
2 https://www.bps.go.id/publication

3 Bakri, Syamsul, Peta Sejarah Peradaban Islam, Yogyakarta: Fajar Media Press, 2011,hlm. 26

${ }^{4}$ Faizatun Alfi Hasanah, Manajemen Dakwah Melalui Pengelolaan Zakat Pada Masa Umar Bin Khattab,Fakultas Dakwah Dan Komunikasi Universitas Islam Negeri Walisongo, Semarang, 2015,hlm.1
} 
mensejahterakan rakyatnya, dari kebijakan tersut menjadikan bahan rujukan untuk generasi selanjutnya dalam mensejahterakan rakyat.salah satunya kebijakan zakat yang menjadi kebijakan fiscal pada saat itu. Bukan hanya zakat hanya kewajiban yang di perintahkan Allah dalam Alqur'an tetapi zakat merupakan solusi yang tepat untuk mengentaskan kemiskinan.

Maka perlu adanya solusi agar senantiasa menjadikan masyarakat miskin lebih berdaya dan memberikan peluang kepada masyarakat miskin untuk mendapatkan akses permodal berwirausaha. Mungkin zakat menjadi Salah solusi. Karena zakat merupakan bagian dari salah satu instrumen dari rukun Islam, zakat bisa digunakan sebagai intermediasi distribusi pendapatan dan kekayaan. Maka dengan berlakunya kewajiban berzakat Adanya penyelenggaraan zakat profesi,zakat fitrah dan zakat maal diharapkan dapat menekan ti ngkat ketimpangan ekonomi di Indonesia, selain itu juga zakat dapat diandalkan sebagai salah satu mekanisme dalam mengatasi masalah kemiskinan yang terjadi di Indonesia, melalui program zakat produktif.

Mengenai hal tersebut, kami sebagai peneliti menyoroti Zakat Sebagai Pengentasan Kemiskinan Dan Pembangunan Perekonomian Umat Ditinjau Dari Pengelolaan Zakat Pada Masa Khulafaur Rasyidin, disini peneliti tertarik untuk melakukan penelitian pada pola Pengentasan Kemiskinan Dan Pembangunan Perekonomian Umat yaitu bagaimana implementasi zakat masa Khulafaur Rasyidin. Fokus penelitian ini, Bagaimana zakat membantu mengentaskan kemiskinan pada masa Khulafaur Rasyidin dan Bagamana Pembangunan Perekonomian Umat pada masa Khulafaur Rasyidin. tujuan dalam penelitian ini diklasifikasikan menjadi dua bagian yaitu: peneliti ingin mengetahui Bagaimana zakat membantu mengentaskan kemiskinan pada masa Khulafaur Rasyidin dan mengetahui Bagamana Pembangunan Perekonomian Umat pada masa Khulafaur Rasyidin.

Penelitian "ini merupakan penelitian sejarah menggunakan pendekatan sejarah" social dengan menjadikan kehidupan sosial-ekonomi pada masa Khulafaur Rasyidin, khususnya berkaitan dengan penerapan zakat sebagai pengentasan kemiskinan dan pembangunan perekonomian umat "sebagai unit analisis (unit of analisys). Data dalam penelitian ini menggunakkan instrumen penelitian kepustakaan (library research). Penelitian ini bersifat penelitian kualitatif, karena tujuan dari penelitian ini adalah untuk memperoleh pemahaman tentang masalah yang diteliti."

\section{Pembahasan}

A. Tinjauan Pustaka Kemiskinan

Ketimpampangan social dalam masalah kekayaan menjadi problem yang selalu dihadapi oleh seluruh lapisan di setiap negara, mulai daerah maju sampai daerah miskin. Pada dasarnya ketimpangan sosial dihitung dengan perolehan pendapatan serta keperluan tiap Negara bisa disebut pendapatan perkapitanya. secara garis besar kemiskinan dapat ditinjau dari dua sisi yaitu:

1. kemiskinan absolut, dapat diidentifikasikan pada besaran jumlah penduduk yang hidup di bawah garis kemiskinan tertentu.

2. kemiskinan relatif, pendapatan nasional yang diterima oleh masingmasing golongan pendapatan.

Dengan kata lain, kemiskinan relatif mempunyai keterkaitan yang 
erat dengan permasalahan distribusi pendapatan. $^{5}$

Ada juga pola kemiskinan yang patut dicatat.

1. pola waktunya, kemiskinan di suatu daerah dapat digolongkan sebagai persistent poverty, yaitu kemiskinan yang telah kronis atau turuntermurun.

2. pola siklus (cyclical poverty), yaitu kemiskinan yang mengikuti siklus ekonomi secara keseluruhan.

3. seasonal poverty, yaitu kemiskinan yang sering dijumpai pada kasuskasus nelayan dan petani tanaman pangan disebut juga kemiskinan musiman.

4. accidental poverty, yaitu kemiskinan karena terjadinya bencana alam atau dampak dari suatu kebijaksanaan tertentu $^{6}$

Islam memiliki sudut pandang, 3 tingkatan yang membahas terkait kemiskinan yaitu:

1. Miskin secara iman, dimaksudkan adalah seseorang yang rukhnya tidak berhubungan dengan Allah, hanya dekat dengan Allah disaat keadaan kesempitan saja.

2. Miskin berdasar ilmu, salah satu yang menjadi penyebab kedua alasan mengapa seseorang mengalami kemiskinan, karena ketidak tahuan bagaimana menemukan penyelesaian permasalahan dalam hidup. Belakangan ini umat muslim sangat enggan untuk mengkaji ilmu-ilmu Allah menyebabkan etos kerja umat muslim menurun.
3. Miskin secara harta, dimaksudkan bahwa sebagai seseorang memiliki kemampuan untuk bekerja dan berusaha dalam rangka memperoleh suatu harta, menghidupi keluarganya secara halal. akan tetapi penghasilan yang didapat masih belum nengcover semua pemenuhan kebutuhan dirinya sendiri beserta keluarganya. ${ }^{7}$

Dilihat dari sisi dimensinya, ketimpangan ekonomi memiliki 3 (tiga) dimensi secara umum, yaitu :

1. Kemiskinan dari sisi politik. Kemiskinan politik yaitu tingkat kemampuan untuk mengakses kekuasaan (power).Kekuasaan meliputi pranata sosial politik yang menentukan kepemilikan sumber daya (resources)untuk kepentingan sekelompok orang atau pranata sosial dan mendapatakan alokasi sumber daya.

2. Kemiskinan dari segi sosial. Disebut dengan kemiskinan social merupakan ketidak mampuan membangun jejaring sosial dapat juga dikatakan terdapatnya faktorfaktor yang menghalangi seseorang untuk memanfaatkan peluang yang ada, dalam memperoleh peluang agar produktivitas seseorang menjadi lebih meningkat. .

3. Kemiskinan dari pandangan Ekonomi, Kemiskinanan ekonomi dapat juga diartikan suatu keadaan dimana terdapat kekurangan sumber daya (resources) yang layak digunakan untuk meningkatkan kesejahteraan sekelompok orang.
5 Sumodiningrat, Gunawan, et.al. 1999. Kemiskinan: Teori, Fakta dan Kebijakan. IMPAC: Jakarta, hlm. 26

6 Sumodiningrat, Gunawan, et.al. 1999. Kemiskinan: Teori, Fakta dan Kebijakan. IMPAC: Jakarta,hlm. 28
7 Jurnal Ekbisi Fakultas Syariah UIN Sunan Kalijaga Yogyakarta Vol. 5, No. 1, Desember 2010, hlm. 42 - 49

8 Tri Widodo, Perencanaan Pembangunan: Aplikasi Komputer (Era Otonomi Daerah), (Yogyakarta: UPP STIM YKPN, 2006). 
B. Pembangunan Perekonomian Umat

Menjadi persoalan besar yang dihadapi setiap umat di zaman ini sebenarnya bagaimana cara pemecahannya dalam rangka Pengembangan ekonomi umat. Pembangunan ekonomi umat ini hanya dapat dilakukan oleh umat Islam itu sendiri, dengan cara mengembalikan aturan-aturan kepada aturan Allah, di antaranya dengan:

1. Membentuk karakter berwirausaha untuk setiap individu.

2. Membangun kemitraan/networking yang kuat dari berbagai pihak usaha yang paling utama sesama muslim.

3. Membuat kebijakan-kebijakan yang lebih memihak kepada pertumbuhan ekonomi umat, dengan cara mensupport secara moril maupun materil yang bersumber dari dana zakat.

4. Menjalankan transaksi dan perilaku ekonomi sesuai dengan aturan-aturan dalan ajaran Islam.

C. Zakat Pada Masa Khufaurasyidin

1. Zakat pada masa Abubakar.

Sepeninggal Rasulullah SAW, Abubakar di daulat sebagai pemimpin umat islam selanjutnya. kebijakan dalam pengelolaan zakat oleh Abu Bakar kegiatan penyelenggaraan pengelolaah secara garis besar seperti apa yang dilakukaan pada masa Rasulullah. Namun, sepeninggal Rosulullah persoalan baru bermunculan, suatu ketika ada kelompok yang mengendahkan penyelenggaraan zakat, di antaranya Musailamah Al-Kadzdzab dari Yamamah serta Sajah Tulaihah. ${ }^{9}$ Menjamurnya

9 Wahbah Al-Zuhayly, Zakat Kajian Berbagai Madzhab, (Bandung: Remaja Rosdakarya. 1995), hlm. 89 para pembangkang zakat dikarenakan pandangan yang keliru Sebagian kaum muslim tentang perintah zakat dalam surat At-Taubah ayat 103 yang berbunyi : "Ambilah sedekah (zakat) dari harta mereka, dari zakat itu kamu membersibkan dan mensucikan mereka,"

Menganggap hanya Nabi yang berhak memerintahkan untuk memungut zakat. Sehingga menilai pemungutan zakat hanya dilakukan Nabi untuk membersihkan dosa. Dan zakat hanya menjadi keharusan kepada mereka ketika Rasullulah masih hidup dan ketika rasul telah wafat maka mereka terbebas dari kewajiban berzakat tersebut. Melihat kondisi demikian, abu bakar dengan tegas membuat kebijakan untuk memerangi mereka yang tidak membayar zakat. Bagi abu bakar mereka yang tidak membayar zakat dianggap golongan orang murtad. Kebijakan abu bakar sempat ditentang oleh Umar bin khattab. Umar bin Khattab berpegang kepada hadist nabi yang menyatakan, "Saya untuk memerangi manusia sampai ia mengucapkan kalimat $\mathrm{La}$ llahaillah". ${ }^{10}$

Menurut umar, Seseorang yang mengucapkan lafaz syahadat berarti sudah masuk Islam. dan sudah dijamin bahwa darah dan kekayaan seseorang berhak memperoleh perlindungan. Sedangkan, Abu Bakar berargumen bahwa teks hadist di atas memberi syarat terjadinya perlindungan tersebut,

10 Abdul Aziz, Kapita selekta Ekonomi Islam Kontemporer, (Bandung: Alfabeta Bandung, 2010), hlm. 111 
yaitu, kecuali bila terdapat kewajiban dalam darah dan kekayaan itu. Abu Bakar juga menganalogikan zakat dengan sholat, karena pentasyri'an keduanya memang sejajar. Zakat adalah yang harus ditunaikan atas kekayaan. Argumen tersebut akhirnya dapat diterima oleh Umar. Ketegasan Abu bakar tergolong luar biasa, dan menjadi sejarah yang tak tertandingi. Abu bakar sama sekali tidak menerima pemisahan antara ibadah jasmaniah (salat) dari ibadah kekayaan (zakat) dan tidak dapat pula menerima pengurangan sesuatu yang pernah diserahkan kepada Rasulullah, walaupun hanya berupa seekor kambing ataupun anaknya.

Tekad abu Bakar untuk memerangi mereka yang tidak membayar zakat, tidak mundur sedikitpun. setiap warga negara yang melakukan pembangkangan tidak mau membayar zakat, pemerintah dapat melakukan penyitaan terhadap aset yang dimiliki. sikap para sahabat utama, termasuk mereka yang pada awalnya tidak setuju, sepakat bahwa pembangkangpembangkang itu harus diperangi karena keengganan mereka membayar salah satu ibadah utama dalam Islam. Dalam memerangi orang-orang yang tidak mau membayar zakat merupakan salah satu masalah konsensus (ijma') dalam hukum Islam. periode Abu Bakar, pertama kali melancarkan perang untuk membela hak-hak fakir miskin dan golongangolongan ekonomi lemah.

Selanjutnya Abu Bakar memulai tugasnya dengan mendistribusikan dan mendayagunakan zakat bagi orangorang yang berhak menerimanya, menurut cara yang dilakukan Rasullulah. Dia sendiri mengambil harta dari Baitul Mal menurut ukuran yang wajar dan diberikan kepada golongan yang berhak menerimanya, dan selebihnya dibelanjakan untuk persediaan bagi angkatan bersenjata yang berjuang di jalan Allah. Abu Bakar saat pembagian zakat tidak membedakan antara terdahulu dan terkemudian masuk Islam. kesemuanya berhak memperoleh zakat apabila kondisi kehidupannya membutuhkan serta masuk dalam kelompok Asnaf penerima zakat yang terdapat dalam surat At-Taubah ayat 60: Sesungguhnya zakat-zakat itu, hanyalah untuk orang-orang fakir, orang-orang miskin, pengurus-pengurus zakat, Para mu'allaf yang dibujuk hatinya, untuk (memerdekakan) budak, orang-orang yang berhutang, untuk jalan Allah dan untuk mereka yuang sedang dalam perjalanan, sebagai suatu ketetapan yang diwajibkan Allah, dan Allah Maha mengetahui lagi Maha Bijaksana.

Abu Bakar dalam mendirikan Baitul Mal di San'ah, yang tempatnya terletak di daratan tinggi Madinah. Beliau tidak mengangkat satu pun pengawal atau pegawai untuk mengawasinya. alasan mengapa tidak mengangkat penjaga, Abu Bakar mengatakan. Jangan takut, tidak ada sedikit pun harta yang tersesisa di dalamnya, semua telah habis dibagikan. dan suatu ketika Abu Bakar meninggal dunia, lalu Umar 
bin Khatab memanggil sahabat terpercaya, di antaranya Abdurrahman bin Auf dan Usman bin Affan untuk masuk dalam Baitul Mal. Mereka tidak mendapatkan satu dinar dan satu dirham pun di dalamnya, kecuali satu karung harta yang tersimpan dalam Baitul Mal yang berisi satu dirham.

2. Zakat pada masa Umar bin Khottob.

Setelah wafatnya Abu bakar Asshidiq, Umar bin khottob diangkat sebagai khalifah selanjutnya. Pada masa kepemimpinan umar bin khattab Semua kabilah menyambut seruan zakat dengan sukarela. Langkah Umar untuk penyelengaran zakat yaitu melantik amil-amil untuk bertugas mengumpulkan zakat dari orang-orang kemudian mendistribusikan kepada golongan yang berhak menerimanya. Dari Sisa zakat itu kemudian diberikan kepada Khalifah, pada situasi tersebut jazirah arab menjadi relatif stabil. Dalam mengelola wilayah persoalan semakin kompleks apalagi wilayah semakin luaas, kemudian Umar memperbaiki struktur pemerintahannya dengan membentuk beberapa lembaga baru yang bersifat akseklusifoperasional, lembaga baru yang di bentuk Umar adalah Baitul Mal.

Penerapan kebijakan lembaga baitul mâlyang di terbitkan Umar bin khotob di antaranya mengklasifikasikan sumber pendapatan negara menjadi empat, yaitu: ${ }^{11}$

a. Pendapatan zakat dari 'ushr. didistribusikan wilayah lokal dan apabila terdapat surplus, maka sisa pendapatan tersebut disimpan di baitul mâl pusat kemudian dibagikan kepada delapan ashnâf, seperti yang telah ditentukan dalam alQur`an.Pendapatan khums atau sedekah.

b. Pendapatan yang didistribusikan kepada fakir miskin untuk membiayai kesejahteraan mereka tanpa membedakan social keagamaan baik seorang muslim atau bukan.

c. Pendapatan

kharâj, fai, jizyah, ‘ushr, dan sewa tanah. Pendapatan ini digunakan untuk membayar dana pensiun dan dana bantuan serta untuk menutupi biaya operasional administrasi, kebutuhan militer, dan sebagainya.

d. Pendapatan lain-lain. Pendapatan ini digunakan untuk membayar para pekerja, pemeliharaan anak-anak terlantar, dan dana sosial lainnya.

Klasifikasi di atas merupakan sumber pendapatan negara yang sangat penting dalam pemerintahan Islam. Salah satu tujuannya adalah agar suatu sumber pendapatan tidak tercampur dengan sumber pendapatan yang lain. Seperti zakat dan pajak. Redistribusi pendapatan hasil zakat, sudah ditentukan oleh Allah dan Rasul-Nya, yaitu kepada 8 golongan (ashnâf) yang berhak mendapatkanya. Sedangkan

11 Adiwarman Azwar Karim, Sejarah Pemikiran Ekonomi Islam, (Jakarta: Rajawali Pers, September 2004), cet. Ke-1, edisi kedua, hlm. 74 
redistribusi pajak dapat ditentukan oleh khalifah. Dan umumnya hasil pemungutan pajak ditujukan untuk pembangunan negara. Karena itulah, para pejabat baitul mâl tidak mempunyai wewenang dalam membuat suatu keputusan terhadap harta baitul mâl yang berupa zakat.

dalam mendistribusikan harta baitul mâl, Umar mendirikan beberapa departemen yang dianggap perlu, seperti ${ }^{12}$

a. Departemen pelayanan militer. Departemen ini berfungsi untuk mendistribusikan dana bantuan kepada orang-orang yang terlibat dalam peperangan. Besarnya jumlah dana bantuan ditentukan oleh jumlah tanggungan keluarga setiap penerima dana.

b. Departemen kehakiman dan ekskutif. Departemen ini bertanggung jawab terhadap pembayaran gaji para hakim dan pejabat ekskutif. Besarnya gaji ini ditentukan oleh dua hal, yaitu jumlah gaji yang diterima harus mencukupi kebutuhan keluarganya agar terhindar dari praktik suap dan jumlah gaji yang diberikan harus sama dan kalaupun terjadi perbedaan, hal itu tetap dalam batas-batas kewajaran.

c. Departemen pendidikan dan pengembangan Islam. Departemen ini mendistribusikan bantuan dana bagi penyebar dan pengembang ajaran Islam beserta keluarganya, seperti guru dan juru dakwah.

d. Departemen jaminan sosial. Departemen ini berfungsi untuk

12 Afzalurrahman, Doktrin Ekonomi Islam. (Yogyakarta: Dana Bhakti Wakaf, 1995), Jilid I, hlm. 169-173. mendistribusikan dana bantuan kepada seluruh fakir miskin dan orang-orang yang menderita.

Selain mendirikan beberapa departemen dalam pendistribusian harta baitul mâl, Umar juga menerapkan prinsip keutamaan dalam mendistribusikannya. Ia tidak senang memberikan bagian yang sama kepada orang-orang yang pernah berjuang menentang Rasulullah saw dengan orangorang yang telah berjuang membela beliau. Menurut pendapatnya bahwa kesulitan yang dihadapi umat Islam harus diperhitungkan jika menetapkan bagian seseorang dari kelebihan harta bangsa itu. Prinsip keadilan menghendaki bahwa usaha seseorang serta tenaga yang telah dicurahkan dalam memperjuangkan Islam harus dipertahankan dan dibalas dengan sebaik-baiknya. ${ }^{13}$

3. Zakat pada masa Usman Bin Affan

Pada masa Usman kondisi ekonomi umat sangat makmur, bahkan diceritakan Usman sampai harus juga mengeluarkan zakat dari harta kharaz dan jizyah yang diterimanya. Harta zakat pada periode Usman mencapai rekor tertinggi dibandingkan pada masamasa sebelumnya, terkait zakat tidak ada perubahan sama sekali, usman hanya melanjutkan kebijakan-kebijakan sebelumnya. Usman melantik Zaid bin Sabit untuk mengelola dana zakat. Pada suatu waktu Usman memerintahkan Zaid untuk membagi-bagikan harta kepada yang berhak namun masih tersisa seribu dirham, lalu Usman

13 ibid 
menyuruh Zaid untuk membelanjakan sisa dana tersebut untuk membangun dan memakmurkan masjid Nabawi.

Pada periode ini wilayah kekhalifahan Islam semakin luas dan pengelolaan zakat semakin sulit terjangkau oleh aparat birokrasi yang terbatas, sehingga perhatian terhadap pengelolaan zakat tidak seperti pada kalifah sebelumnya, Selain itu sumber pendapatan negara selain zakat yang memadai, yakni kharaj dan jizyah. Sehingga khalifah lebih fokus dalam pengelolaan pendapatan negara yang lain seperti kharaj dan jizyah yang besaran Presentasinya dapat diubah, berbeda dengan zakat yang besarannya harus mengikuti tuntunan syariat.

Khalifah Utsman ibn Affan tetap mempertahankan system pemberian bantuan dan santunan serta memeberikan sejumlah besar uang kepada masyarakat yang berbeda-beda. Meskipun meyakini prinsip persamaan dalam memenuhi kebutuhan pikok masyarakat, ia memberikan bantuan yang berbeda pada tingkat yang lebih tinggi. Dengan demikian, dalam pendistribusian harta Baitul Mal, Khalifah Utsman ibn Affan menerapkan prinsip keutamaan seperti halnya Umar ibn al-khattab. Hanya saja untuk mengamankan zakat dari berbagai gangguan dan masalah dalam pemeriksaan kekayaan yang tidak jelas oleh beberapa oknum pengumpul zakat Khalifah utsman ibn Affan mendelegasikan kewenangan menksir harta yang dizakati kepada para pemiliknya msiang-masing.
Khalifah Utsman ibn Affan membuat beberapa perubahan administrasi tingkat atas dan pergantian beberapa gubenur. Dan juga menerapkan kebijakan membagi-bagikan tanah-tanah Negara kepada individu-individu untuk reklamasi dan kontribusi kepada Baitul Mal. Dari hasil kebijakannya ini, Negara memperoleh pendapatan sebesar 50 juta dirham atau naik 41 juta dirham jika dibandingkan pada masa Umar ibn al-Khattab yang tidak membagi- bagikan tanah tersebut."'Hal ini dilakukan karena Negara membutuhkan dana tambahan"untuk meningkatkan pengeluaran di bidang pertahanan dan kelautan, meningkatkan dana pensiun, dan pembangunan berbagai wilayah taklukan baru. ${ }^{14}$

Memasuki enam tahun kedua masa pemerintahan Utsman Ibn Affan, tidak terdapat perubahan situasi ekonomi yang cukup signifikan. Berbagai kebijakan Khalifah Utsman ibn Affan yang banyak menguntungkan keluarganya telah menimbulkan benih kekecewaan yang mendalam pada sebagian besar kaum muslimin. Akibatnya, pada masa ini, pemerintahannya lebih banyak diwarnai kekacauan politik yang berakhir dengan terbunuhnya sang khalifah.

4. Zakat masa khalifah Ali bin Abi thalib

Setelah wafatnya Usman bin Affan, Ali bin abi thalib diangkat sebagai khalifah selanyutnya. Diawal masa pemerintahanya Ali

14 Azyumaryadi Azra, Sejarah Pemikiran Ekonomi Islam, (Jakarta: Gramarta Publishing, 2010), hlm. 95-96 
bin Abi thalib membuat beberapa kebijakan terobosan diantaranya memberhentikan para pejabat yang korupsi, membuka kembali lahan perkebunan yang telah diberikan kepada orang-orang kesayangan Utsman dan mendistribusikan pendapatan pajak tahunan sesuai dengan ketentuan yang telah ditetapkan Umar ibn al-Khattab.

Berbagai kebijakan tegas yang diterapkannya menimbulkan api permusuhan dengan keluarga Bani Umayyah yang dimotori oleh Muawiyah ibn Abi Sofyan. Pemberontakan juga datang dari golongan Khawariij, mantan pendukung Khalifah Ali Ibn Abu Thalib yang kecewa terhadap keputusan tahkim pada

perang shiffin. Selain itu Ia harus menghadapi pemberontakan Thalhah, Zubair ibn al-Awwam, dan Aisyah yang menuntut kematian Utsman ibn Affan.

Khalifah Ali ibn Abi Thalib tetap berusaha untuk melaksanakan berbagai kebijakan yang mendorong peningkatan kesejahteraan umat islam. Menurut sebuah riwayat, ia secara sukarela menarik diri dari daftar penerima dana bantuan Baitul Mal. Selama masa pemerintahannya Khalifah Ali ibn Abi Thalib menetapkan pajak terhadap hasil hutan dan sayuran.

Selama masa pemerintahan Ali ibn Abi Thalib, system administrasi Baitul Mal, baik diangkat pusat maupun daerah, telah berjalan dengan baik. Kerjasama antara keduannya berjalan dengan lancer maka pendaptaan baitul Mal mengalami surplus. Dalam pendistribusian harta Baitul Mal, khalifah Ali Ibn AbinThalib menerapkan prinsip pemerataan. Ia memberikan santunan yang sama kepada setiap orang tanpa memandang status social atau kedudukannya di dalam Islam. Khalifah Ali ibn Abi Thalib tetap berpendapat bahwa seluruh pendapatan Negara yang disimpan dalam Baitul Mal harus didistribusikan kepada kaum muslimin, tanpa ada sedikitpun dana yang tersisa. Distribusi tersebut dilakukan sekali dalam sepekan. Hari kamis merupakan hari pendistribusian atau hari pembayaraan. Pada hari itu, semua penghitungan diselesaikan dan, pada hari sabtu penghitungan baru dimulai ${ }^{15}$

Kebijakan Ekonomi Ali Bin Ali Thallib antara lain :
a. Mengedepankan prinsip pemerataan dalam pendistribusian kekayaan negara kepada masyarakat.

b. Menetapkan pajak terhadap para pemilik kebun dan mengijinkan pemungutan zakat terhadap sayuran segar

c. Pembayaran gaji pegawai dengan system mingguan

d. Melakukan kontrol pasar dan pemberantas pedagang licik, penimbunan barang, dan pasar gelap

e. Aturan konpensai bagi para pekerja jika kereka merusak barang-barang pekerjaaannya

D. Program Pengentasan Kemiskinan BAZNAS.

Allah tidak akan membebani hamba-Nya melebihi kemampuanya,

15 Azyumaryadi Azra, Sejarah Pemikiran Ekonomi Islam, (Jakarta: Gramarta Publishing, 2010), hlm. 97 
seorang muslim diwajibkan untuk membayar zakat bagi yang mampu. Sebaliknya, bagi muslim yang tidak mampu berusaha dan tidak sanggup bekerja, serta tidak memiliki harga untuk mencukupi kebutuhan hidupnya, ia berhak mendapatkan jaminan social dari saudara-saudaranya yang mampu. Jaminan ini berupa zakat, yang diharapkan mampu mengentas kemiskinan di masyarakat. Sehingga penerima zakat (mustahik) benar-benar lepas dari kemiskinan, dengan bisa mencukupi kebutuhan hidupnya, dan menjadi golongan orang yampng mampu membayar zakat (Muzaki).

Badan amal zakat nasional Dalam rangka mengurangi angka kemiskinan dan meningkatkan manfaat zakat. mengakomodir kebutuhan mustahik secara prima dengan mendayagunakan zakat di bidang sosial dan ekonomi. Masing-masing Baznas setiap daerah mempunyai progam masing-masing yang sesuai dengan kebutuhan di daerah tersebut. akan tetapi . dalam skala nasional Badan Amil Zakat Nasional membentuk program Layanan Aktif BAZNAS (LAB) sebagai program khusus divisi Pendistribusian dan Pendayagunaan Zakat (DPP). Layanan Aktif BAZNAS (LAB) adalah merupakan salah satu progam pengentasan kemiskinan dan program layanan darurat sosial untuk mustahik dengan model penanganan tepat sasaran, tepat waktu (cepat) dan tepat penanganan. Hadirnya LAB diharapkan untuk bisa menyalurkan dana zakat sesuai ketentuan tersebut. ${ }^{16}$

Layanan Aktif BAZNAS (LAB) salah satu tujuanya Untuk melayani mustahik yang diketegorikan dalam keadaan darurat. LAB dalam pelaksanaanya dibagi ke dalam beberapa unit, yaitu melalui Unit Layanan, Unit Respon dan ATM Beras. Terkhusus unit layanan dan unit respon melayani jenis layanan bantuan akses tempat tinggal (biaya kontrakan dan atau renovasi rumah), bantuan akses pengobatan dan atau kesehatan, bantuan akses pendidikan, bantuan akses konsumsi (biaya hidup, pakaian, dan atau ATM Beras), bantuan akses transportasi, dan bantuan hutang untuk pemenuhan biaya hidup dasar. Untuk menjalankan program $\mathrm{LAB}$, agar berjalan sesuai dengan yang diharapkan dan benar-benar tepat sasaran dan fungsinya. maka dalam menjalankan tugasnya, Layanan Aktif BAZNAS menyelenggarakan harus bisa menjalankan fungsi:

1. Perencanaan; meliputi perencanaan kegiatan, keuangan, dan sumber daya manusia

2. Pelaksanaan; adalah implementasi operasional kegiatan yang direncanakan. Ini terbagi menjadi beberapa cluster yang meliputi kebutuhan biaya hidup, kesehatan, pendidikan, dan renovasi rumah.

3. Pengendalian; meliputi monitoring dan evaluasi atas pelaksanaan kegiatan program.

4. Pelaporan; pertanggungjawaban terhadap perencanaan implementasi kegiatan, target, sasaran, serta penggunaan anggaran

Selain itu Badan Amil Zakat Nasional juga membangun kolaborasi bersama dengan pemerintah melalui kementerian social (Kemensos) untuk mengentaskan kemiskinan. Dengan kolaborasi dengan kemensos diharapkan bisa membuat progam yang berkesinambungan untuk mewujudkan pengentasan

16 www.baznas.go.id (akses, 17 agt $2020 \mathrm{Pkl}$ 19.45) 
kemiskinan. ${ }^{17}$ dalam rangka pembangunan perekonomian umat, badan amil zakat Nasional diharapkan Bukan hanya sekedar mengentaskan kemiskinan penerima zakat yang kurang mampu, akan tetapi juga bisa memberikan dampak signifikan terhadap pembangunan perekonomian umat. Seseorang yang awalnya mustahik dengan adanya zakat diharapkan mampu merubah keadaanya menjadi pemberi zakat (muzaki) dengan terangkatnya mustahik secara bersamaan pembangunan perekonomian umat terbentuk.

Dalam artian disini Baznas tidak hanya sekedar memberikan pelayanan namun juga mampu memberikan pendayagunaan, agar perekonomian masyarakat bisa berkembang. Badan Amil Zakat Nasional terus mengembangkan dan memperkuat berbagai model program ekonomi berbasis dana zakat untuk memberdayakan umat khususnya warga kurang mampu dan golongan mustahik (penerima zakat) lainnya. Melalui program ini, Badan Amil Zakat Nasional ingin membangun paradigma, jiwa dan mental sukses serta menanamkan nilai-nilai spiritual dan kaidah-kaidah syariah dalam bisnis. Di bulan ramadhan $(1440 \mathrm{H})$ Baznas meluncurkan 9 program unggulan pendayagunaann, yang diharapkan mampu menjadi motor pembangun perekonomian umat, program tersebut diantaranya; Program pendayagunaan yang dilakukan Baznas antara lain, program pemberdayaan Zakat Mart, Mustahik

17 https://republika.co.id/berita//entaskankemiskinan-baznas-dan-kemensos-berkolaborasi. Diakses 17 agt 2020. Pkl 22.30
Pengusaha, Pelatihan Kewirausahaan UKM dan Mustahik Mikro ${ }^{18}$

Selain itu baznas juga membuat program Bazar Mitra Usaha Micro Finance, Jambore Cah Angon, Gulai Ramadan, dan Zakat Community Development (ZCD) Jakarta. Program pendayagunaan Baznas selama Ramadhan, memberdayakan para mustahik sehingga harapanya mereka bisa tumbuh berkembang, meningkatkan perkonomian, dan kesejahteraan. Pada tahun 2016 Baznas juga telah membangun tiga lembaga dalam kerangka program pemberdayaan ekonomi dalam waktu berdekatan, yaitu Sekolah Wirausaha (Sewira), LP4 (Lembaga Pusat Pengembangan Pertanian dan Peternakan) serta LPMP (Lembaga Pemberdayaan Mustahik Pengusaha). ${ }^{19}$

Sekolah Wirausaha (sewira) merupakan lembaga pendidikan dan pelatihan enterpreneurship bagi mustahik berumur 19-30 tahun yang memiliki tekad menjadi pengusaha. Lembaga ini melibatkan praktisi, profesional, akademisi serta para tokoh pengusaha muslim sukses dan berkompeten. Lembaga ini diharapkan bisa membangun jaringan pengusaha untuk saling membantu dalam mengingkatkan dan mengembangkan usaha. Rencana hingga 2021, Baznas bisa mencetak 5.000 usahawan baru. Sedangkan LP4, merupakan lembaga yang memberdayakan sekaligus memproteksi peternak dan petani. Pendirian lembaga ini dilatarbelakangi

\footnotetext{
${ }^{18}$ https://republika.co.id/berita/prakn0396/1 8-program-unggulan-baznas-layani-46961mustahik 17 agt 2020 pkl. 20.12

19 https://republika.co.id/berita/duniaislam/wakaf/16/10/29/ofswq1313-baznaskembangkan-program-ekonomi-berbasis-danazakat 17 agt 2020. 22.30wib
} 
kondisi petani dan peternak saat ini yang sebagian besar masih miskin. Sementara itu, Lembaga Pemberdayaan Mustahik Pengusaha (LPMP) yang diluncurkan oleh Ketua BAZNAS Bambang Sudibyo bersama Wakil Ketua Baznas Zainulbahar Noor awal Oktober 2016, bertujuan untuk meneguhkan zakat sebagai energi perubahan kepada para mustahik yang menjadi pelaku usaha mikro untuk meningkatkan pertumbuhan, keberkahan dan pengembangan usaha.

E. Relevansi Pengelolaan Zakat Pada Masa Khulafaur Rasyidin

Relevansi pengelolaan zakat pada masa Khulafaur Rasyidin dapat dijelaskan pada table berikut :

Tabel 1: Zakat Pada Masa Khulafaur Rasyidin

\begin{tabular}{|c|c|}
\hline $\begin{array}{l}\text { Khulafaur } \\
\text { Rasyidin }\end{array}$ & Kebijakan zakat \\
\hline Abu bakar & $\begin{array}{lr}\text { 1. } & \text { Kewajiban membayar } \\
\text { zakat(yang tidak } \\
\text { membayar zakat } \\
\text { dianggap golongan } \\
\text { orang murtad) } \\
\text { 2. Zakat adalah yang } \\
\text { harus ditunaikan atas } \\
\text { kekayaan } \\
\text { 3. melakukan penyitaan } \\
\text { terhadap aset yang } \\
\text { dimiliki } \\
\text { 4. mendirikan Baitul Mal } \\
\text { di San'ah } \\
\text { mendistribusikan"dan } \\
\text { mendayagunakan zakat } \\
\text { bagi orang-orang yang } \\
\text { berhak menerimanya" } \\
\text { 6embagian zakat"tidak } \\
\text { membedakan antara } \\
\text { terdahulu dan } \\
\text { terkemudian masuk } \\
\text { Islam" }\end{array}$ \\
\hline Umar bin & 1. Pendapatan zakat dan \\
\hline
\end{tabular}

\begin{tabular}{|c|c|}
\hline Khottob & 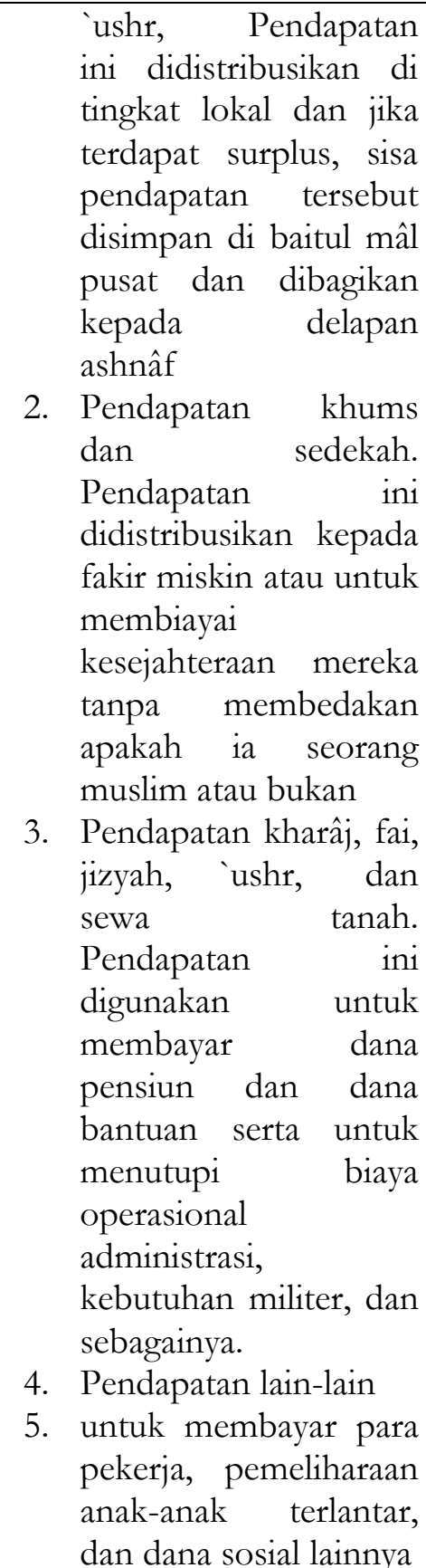 \\
\hline $\begin{array}{l}\text { Usman } \\
\text { Bin Affan }\end{array}$ & 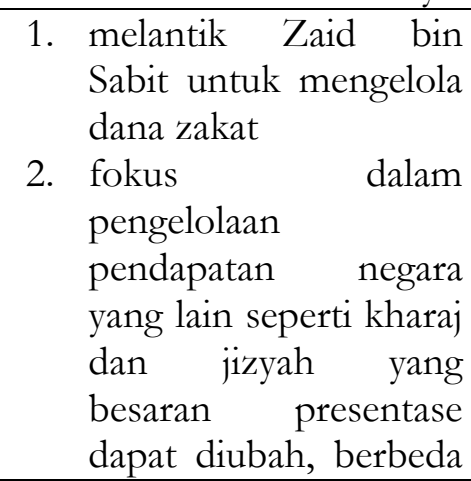 \\
\hline
\end{tabular}




\begin{tabular}{|c|c|}
\hline & 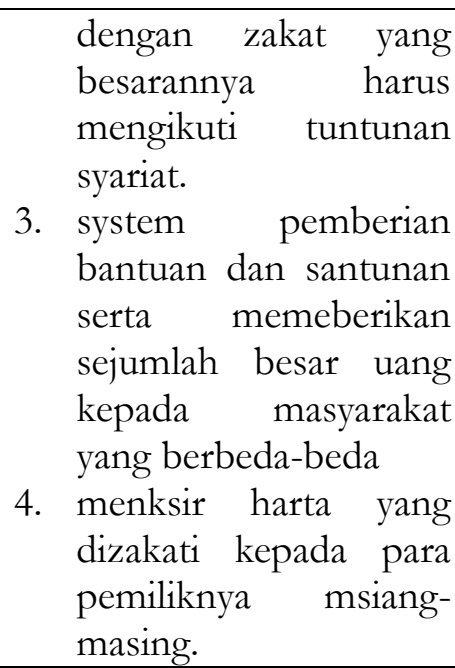 \\
\hline $\begin{array}{l}\text { Ali bin Abi } \\
\text { thalib }\end{array}$ & 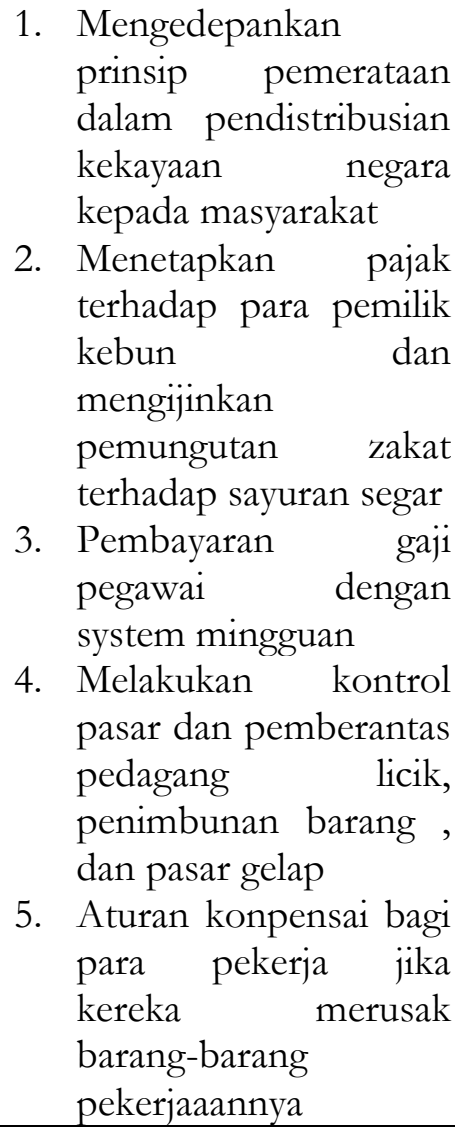 \\
\hline
\end{tabular}

Dimensi dan sudut pandang Islam, mengenai kemiskinan terbagi menjadi 3 (tiga), yaitu:

Tabel 2: Dimensi dan sudut pandang Islam kemiskinan

\begin{tabular}{|c|l|}
\hline Dimensi & $\begin{array}{l}\text { Sudut } \\
\text { Pandang }\end{array}$ \\
\hline 1. Kemiskinan politik & 1. Miskin \\
\hline
\end{tabular}

\begin{tabular}{|c|c|}
\hline $\begin{array}{l}\text { tingkat } \\
\text { kemampuan untuk } \\
\text { mengakses } \\
\text { kekuasaan } \\
\text { (power).Kekuasaan } \\
\text { meliputi pranata } \\
\text { sosial politik yang } \\
\text { menentukan } \\
\text { kepemilikan } \\
\text { sumber daya } \\
\text { (resources)untuk } \\
\text { kepentingan } \\
\text { sekelompok orang } \\
\text { atau pranata sosial } \\
\text { dan mendapatakan } \\
\text { alokasi sumber } \\
\text { daya. }\end{array}$ & $\begin{array}{l}\text { iman } \\
\text { orang yang } \\
\text { jiwanya tidak } \\
\text { ada kontak } \\
\text { atau } \\
\text { hubungan } \\
\text { dengan Allah, } \\
\text { atau jika ada } \\
\text { hubungan pun } \\
\text { terlalu tipis, } \\
\text { yaitu hanya } \\
\text { ingat pada } \\
\text { Allah saat } \\
\text { susah saja. }\end{array}$ \\
\hline $\begin{array}{l}\text { 2. Kemiskinan social } \\
\text { kemiskinan } \\
\text { ketidakmampuan } \\
\text { membangun } \\
\text { jaringan sosial dan } \\
\text { struktur yang } \\
\text { mendukung dalam } \\
\text { memperoleh } \\
\text { peluang agar } \\
\text { produktivitas } \\
\text { seseorang } \\
\text { meningkat. } \\
\text { Kemiskinan sosial } \\
\text { dapat dikatakan } \\
\text { terdapatnya faktor- } \\
\text { faktor yang } \\
\text { menghambat dan } \\
\text { menghalangi } \\
\text { seseorang untuk } \\
\text { memanfaatkan } \\
\text { peluang yang ada. }\end{array}$ & $\begin{array}{l}\text { 2. Miskin ilmu } \\
\text { miskin ilmu } \\
\text { ini menjadi } \\
\text { penyebab } \\
\text { yang kedua } \\
\text { mengapa } \\
\text { manusia } \\
\text { miskin dan } \\
\text { tidak tahu cara } \\
\text { menyelesaikan } \\
\text { masalah } \\
\text { hidup. Saat ini } \\
\text { etos kerja } \\
\text { umat muslim } \\
\text { sangat rendah, } \\
\text { mereka } \\
\text { enggan untuk } \\
\text { mengkaji } \\
\text { ilmu-ilmu } \\
\text { Allah }\end{array}$ \\
\hline $\begin{array}{lr}\text { 3. Kemiskinan } & \\
\text { Ekonomi } & \\
\text { kondisi dimana } & \text { derdapat } \\
\text { kekurangan } & \\
\text { sumber } & \text { daya } \\
\text { (resources) yang } \\
\text { digunakan untuk } \\
\text { meningkatkan }\end{array}$ & $\begin{array}{l}\text { 3. Miskin } \\
\text { harta } \\
\text { seseorang } \\
\text { yang masih } \\
\text { memiliki } \\
\text { kemampuan } \\
\text { untuk bekerja } \\
\text { berusaha } \\
\text { dalam rangka }\end{array}$ \\
\hline
\end{tabular}




\begin{tabular}{|l|l|}
\hline kesejahteraan & memperoleh \\
sekelompok orang & harta dan \\
& menghidupi \\
keluarganya \\
secara halal \\
tetapi hasil \\
yang didapat \\
masih belum \\
mencukupi \\
bagi dan \\
pemenuhan \\
kebutuhan \\
dirinya dan \\
keluarganya \\
\hline
\end{tabular}

Aturan-aturan Allah yang telah diatur demi kesuksesan semua umat manusia, di antaranya dengan:

1. Menanamkan sifat wirausaha bagi setiap individu umat.

2. Membangun kemitraan/ jejering yang kuat dengan berbagai pihak terutama dengan sesame muslim

3. Membuat kebijakan-kebijakan yang lebih memihak kepada pertumbuhan ekonomi umat, dengan cara mensupport secara moril maupun materil yang bersumber dari dana zakat

4. Menjalankan transaksi dan perilaku ekonomi sesuai dengan aturan-aturan dalan ajaran Islam

\section{Pembangunan Perekonomian}

Umat, Badan Amil Zakat Nasional

1. mengembangkan dan memperkuat berbagai model program ekonomi berbasis dana zakat

2. membangun paradigma, jiwa dan mental sukses serta menanamkan nilai-nilai spiritual dan kaidahkaidah syariah dalam bisnis

3. meluncurkan 9 program unggulan pendayagunaann, yang diharapkan mampu menjadi motor pembangun perekonomian umat, program tersebut diantaranya; Program pendayagunaan yang dilakukan Baznas antara lain, program pemberdayaan ZMart, Mustahik Pengusaha, Pelatihan Kewirausahaan UKM, Mustahik Mikro, dan Pemberdayaan Petani Beras Fitrah

F. Relevansi Zakat Membantu Mengentaskan Kemiskinan Pada Masa Khulafaur Rasyidin

Dalam konteks pengentasan kemiskinan zaman khulafaur Rasyidin sebagai berikut: pada zaman Abubakar, zakat mendistribusikan dan mendayagunakan zakat bagi orang-orang yang berhak menerimanya. Umar bin Khottob, Pendapatan ini didistribusikan kepada fakir miskin atau untuk membiayai kesejahteraan mereka tanpa membedakan apakah ia seorang muslim atau bukan dan untuk membayar para pekerja, pemeliharaan anak-anak terlantar, dan dana sosial lainnya. Usman Bin Affan, system pemberian bantuan dan santunan serta memeberikan sejumlah besar uang kepada masyarakat yang berbedabeda.

G. Relevansi Pembangunan Perekonomian Umat pada masa Khulafaur Rasyidin

Dalam konteks, Pembangunan Perekonomian Umat pada masa Khulafaur Rasyidin sebagai berikut: Pada zaman Abu bakar, mendirikan Baitul Mal di San'ah. Umar bin Khottob, Pendapatan kharâj, fai, jizyah, ushr, dan sewa tanah. Pendapatan ini digunakan untuk membayar dana pensiun dan dana bantuan serta untuk menutupi biaya operasional administrasi, kebutuhan militer, dan sebagainya. Usman Bin Affan, fokus dalam pengelolaan pendapatan negara yang lain seperti 
kharaj dan jizyah yang besaran presentase dapat diubah, berbeda dengan zakat yang besarannya harus mengikuti tuntunan syariat. Ali bin Abi thalib, Mengedepankan prinsip pemerataan dalam pendistribusian kekayaan negara kepada masyarakat, Menetapkan pajak terhadap para pemilik kebun dan mengijinkan pemungutan zakat terhadap sayuran segar, Melakukan kontrol pasar dan pemberantas pedagang licik, penimbunan barang, dan pasar gelap.

\section{Kesimpulan}

Zakat memiliki peran dan fungsi secara bersamaan, secara sepiritual dan social maka zakat dapat menjadi solusi di dalam masalah kemiskinan dan pembangunan perekonomian. Pada masa pemerintahan Khulafaurasyidin zakat menjadi instrument utama dalam mengentaskan kemiskinan. Setiap kholifah pada waktu itu secara umum memungut zakat dengan maksimal dan membagikanya kepada mustahik, Artinya ada semangat memberantas kemiskinan pada masa khalifah. Bahkan pada masa khalifah Abu bakar sampai memerangi orang yang tidak mau membayar zakat dan mengambil asset yang tidak dizakati.

Dalam pembangunan ekonomi umat keseluruhan khulafaurasyidin membuat lembaga baitu maal, dan juga menghimpun klasifikasi pendapatan untuk meningkatkan pendapatan Negara. Pada masa khalifah umar bin khottob mengklasifikasi penghimpunan pendapatan seperti karaj, khums, fai, jizyah, ushr, dan sewa tanah. hal ini sangat penting karena mernjadi instrument fiskal zaman khulafaur rasyidin sebagai bahan rujukan dan dasar membuat kebijakan pungutan serta pensarufan zakat. Sedangkan pada masa Usman bin affan menerapkan kebijakan membagi-bagikan tanah-tanah Negara kepada individu- individu untuk reklamasi dan kontribusi kepada Baitul Mal. dengan kebijakan ini terbukti menjadi sarana penguatan perekonomian yang mendorong perputaran perekonomian di masyarakat. Alhasil angka pendapatan zakat meningkat dari sebelumnya.

Dilain sisi Baznas selaku pelaksana penghimpun zakat dan penyalur zakat di Indonesia memiliki program-program yang mengarah pada pengentasan kemiskinan dan pembangunan ekonomi umat. Dalam pengentasan kemiskinan Baznas memberikan layanan prima dengan membuat program Layanan Aktif BAZNAS (LAB). salah satu tujuanya LAB Untuk melayani mustahik yang diketegorikan dalam keadaan darurat. LAB dalam pelaksanaanya dibagi ke dalam beberapa unit, yaitu melalui Unit Layanan, Unit Respon dan ATM Beras. Terkhusus unit layanan dan unit respon melayani jenis layanan bantuan akses tempat tinggal (biaya kontrakan dan atau renovasi rumah), bantuan akses pengobatan dan atau kesehatan, bantuan akses pendidikan, bantuan akses konsumsi (biaya hidup, pakaian, dan atau ATM Beras), bantuan akses transportasi, dan bantuan hutang untuk pemenuhan biaya hidup dasar.

Dalam membangun ekonomi umat Baznas juga menjalakan programprogram pendayagunaan zakat, adapun program yang dibuat untuk membina dan mengkaryakan mustahik diantaranya yaitu Sekolah Wirausaha (Sewira), LP4 (Lembaga Pusat Pengembangan Pertanian dan Peternakan) serta LPMP (Lembaga Pemberdayaan Mustahik Pengusaha). 


\section{Daftar Pustaka}

Abdillah, Kudrat, Maylissabet, M. Taufiq, Kontribusi Bahtsul Masail Pesantren di Madura dalam Menghadapi Perkembangan Hukum Islam Kontemporer, Jurnal Perada: Jurnal Studi Islam Kawasan Melayu, 2019.

Abdul Aziz, Kapita selekta Ekonomi Islam Kontemporer, (Bandung: Alfabeta, 2010)

Adiwarman Azwar Karim, Sejarah Pemikiran Ekonomi Islam, (Jakarta: Rajawali Pers, 2004)

Afzalurrahman, Doktrin Ekonomi Islam, (Yogyakarta: Dana Bhakti Wakaf, 1995)

Azyumaryadi Azra, Sejarah Pemikiran Ekonomi Islam, (Jakarta: Gramarta Publishing, 2010)

Bakri, Syamsul, Peta Sejarah Peradaban Islam, Yogyakarta: Fajar Media Press, 2011)

Faizatun Alfi Hasanah, Manajemen Dakwah Melalui Pengelolaan Zakat Pada Masa Umar Bin Khattab, Fakultas Dakwah Dan Komunikasi Universitas Islam Negeri Walisongo ,Semarang, 2015.

https://digilib.uinsby.ac.id

https://www.bps.go.id/publication

Jurnal Ekbisi Fakultas Syariah UIN Sunan Kalijaga Yogyakarta Vol. 5, No. 1, Desember 2010.

Pertumbuhan Ekonomi Indonesia Triwulan I-2020 No. 39/05/Th. XXIII, 5 Mei 2020

Sumodiningrat, Gunawan, et.al. 1999. Kemiskinan: Teori, Fakta dan Kebijakan. IMPAC: Jakarta.

Taufiq, M, Optimalisasi Peran Dewan Pengawas Syariah di Lembaga Kenangan Mikro Syariah, Al Huquq : Journal of Indonesian Islamic Economic Law, 2020.

Taufiq, M., dan Muklisin Purnomo, Model Pemberdayaan Aset Wakaf Masjid Secara Produktif Di Masjid Jogokariyan Yogyakarta, Jurnal Perada: Jurnal Studi Islam Kawasan Melayu, 2018.
Tri Widodo, Perencanaan Pembangunan: Aplikasi Komputer, Era Otonomi Daerah, (Yogyakarta: UPP STIM YKPN, 2006)

Wahbah Al-Zuhayly, Zakat Kajian Berbagai Madzhab, (Bandung: Remaja Rosdakarya, 1995) 